\title{
Long term follow up of growth in children with Congenital Adrenal Hyperplasia 21- Hydroxylase deficiency
}

\author{
Ruchi Parikh*, Sudha Rao, Meena Desai, Ruchi Shah, Poonam Singh, Neha Dighe, Rajesh Joshi, Aparna Limaye
}

From 8th APPES Biennial Scientific Meeting

Darwin, Australia. 29 October - 1 November 2014

Obesity and decreased final height are described in children with CAH 21OHD. Of 119 children (50 M, 69F;79 Salt Wasters(SW), 40 Simple Virilizers (SV)) diagnosed over 24 years, various growth parameters were studied in 43 children with regular follow up for 5 years or more.

Clinical data, anthropometry, genotype, hormonal and biochemical profile were evaluated at presentation. On follow up, growth and clinical characteristics, metabolic control (8am 17OH-Progesterone), bone age and replacement doses of gluco-corticoid (GC) and mineralo-corticoid (MC) were studied. Growth parameters were expressed as SDS. Obesity, defined as BMI SDS $>/=2$ and short stature, defined as Ht SDS $</=-2$ were correlated with all the variables, using Unpaired $\mathrm{T}$ Test, Pearson Correlation and One way ANOVA Test.

43 children (16M, 27F; 32SW, 11SV; 36 mutations proven) had a mean duration of follow up of $11+/$ 4.14 years. At last follow up, Ht SDS was $</=-2$ in 27.9\% cases $(\mathrm{N}=12 / 43: 4 \mathrm{M}, 8 \mathrm{~F} ; 9 \mathrm{SW}, 3 \mathrm{SV})$. Age at onset of puberty $(\mathrm{p}=0.035)$, higher $\mathrm{GC}$ dose at presentation $(>40 \mathrm{mg} / \mathrm{m} 2)(\mathrm{p}=0.034)$ and at 3 years of age $(\mathrm{p}=0.047)$ and use of Hydrocortisone and/or Prednisolone $(\mathrm{p}=0.002)$ had a negative correlation with Ht SDS. 6 (13.95\%) children (1M, 5F; 6SW) had achieved Adult Height (AH) SDS of $-2.36+/-1.25$, and AH SDS $-\mathrm{TH}$ SDS (Target Height) was $-0.11+/-1.23$. BMI SDS $>/=2$ found in $32.6 \%$ cases $(\mathrm{N}=14 / 43$ : $2 \mathrm{M}, 12 \mathrm{~F} ; 8 \mathrm{SW}, 6 \mathrm{SV})$ correlated positively with 17 OHP values $(\mathrm{p}=0.013)$. Girls were heavier than boys $(p=0.006)$. Adiposity rebound occurred at 4 years for both the genders. At the time of study analysis, Ht SDS showed a distinct

Bai Jerbai Wadia Hospital for Children, Mumbai, Maharashtra, India shift to the left and BMI SDS, a distinct shift to the right of mean of the reference population as cited [1].

In the present series, there was a higher incidence of obesity (32.6\%) but short stature was noted in $27.9 \%$ only. Aggressive lifestyle management, dietary control, optimizing dose of therapy (GC) and regular monitoring should be an integral part of long term management of patients with CAH 21OHD.

Published: 28 April 2015

Reference

1. Agarwal KN, Agarwal DK: Indian Pediatrics 1992, 29:1203, 1994; 31:377, 2001; 38:1217-35.

doi:10.1186/1687-9856-2015-S1-P47

Cite this article as: Parikh et al.: Long term follow up of growth in children with Congenital Adrenal Hyperplasia 21- Hydroxylase deficiency. International Journal of Pediatric Endocrinology 20152015 (Suppl 1):P47

Submit your next manuscript to BioMed Central and take full advantage of:

- Convenient online submission

- Thorough peer review

- No space constraints or color figure charges

- Immediate publication on acceptance

- Inclusion in PubMed, CAS, Scopus and Google Scholar

- Research which is freely available for redistribution

Submit your manuscript at www.biomedcentral.com/submit C Biomed Central 